\title{
PETA RENCANA (ROADMAP) RISET ENTERPRISE RESOURCE PLANNING (ERP) DENGAN FOKUS RISET PADA USAHA KECIL DAN MENENGAH (UKM) DI INDONESIA
}

\author{
J.W. Saputro ${ }^{1}$, Putu Wuri Handayani ${ }^{2}$, Achmad Nizar Hidayanto ${ }^{2}$, dan Indra Budi ${ }^{2}$
}

${ }^{1}$ University of Wisconsin, Madison, Union South, Suite 329, 1308 W. Dayton St., 53715, USA

${ }^{2}$ Fakultas Ilmu Komputer, Universitas Indonesia, Kampus Baru UI Depok, Jawa Barat, 16424, Indonesia

E-mail: putu.wuri@cs.ui.ac.id

\begin{abstract}
Abstrak
Usaha Kecil dan Menengah (UKM) di Indonesia telah dapat berkontribusi terhadap PDB (Produk Domestik Bruto) nasional sebesar 55.56\% berdasarkan data Biro Perencanaan Kementerian Negara Koperasi dan UKM Republik Indonesia, pada tahun 2008. Untuk memperluas pangsa pasar dan meningkatkan daya saing UKM, UKM membutuhkan suatu aplikasi yang dapat mengintegrasikan dan mengotomatisasi proses bisnis UKM. Aplikasi ERP dapat menjadi salah satu solusi untuk UKM dikarenakan keuntungan yang dapat diberikan seperti memberikan informasi dengan waktu respon yang cepat, meningkatkan interaksi antar bagian dalam suatu organisasi, meningkatkan pengelolaan siklus pemesanan barang, dsb. Beberapa isu kritis yang dihadapi oleh UKM adalah terbatasnya dana dan kapabilitas teknologi informasi yang dimiliki. Dalam memahami kebutuhan layanan yang diperlukan oleh UKM untuk aplikasi ERP dan untuk menyediakan arahan bagi UKM serta menanggapi kurangnya riset ERP di Indonesia maka riset ini bertujuan untuk menggambarkan peta rencana jangka panjang dari agenda riset ERP yang akan dilakukan untuk UKM di Indonesia.
\end{abstract}

Kata Kunci: ERP,UKM, Indonesia

\begin{abstract}
Small and Medium Enterprises (SMEs) in Indonesia has been able to contribute to the GDP (Gross Domestic Product) of $55.56 \%$ based on national data Planning Bureau of the Ministry of Cooperatives and SMEs of the Republic of Indonesia, in 2008. To expand market share and improve the competitiveness of SMEs, SMEs need an application that can integrate and automate business processes of SMEs. ERP applications can be one solution for SMEs because of the advantages that can be provided such as providing information with fast response time, increase the interaction between the departments of an organization, improving the management of ordering goods cycle, etc. Some of the critical issues faced by SMEs are the limited funds and information technology capabilities they have. In understanding the needs of the services required by SMEs for ERP applications and to provide guidance for SMEs and response to the lack of research about ERP in Indonesia, this research aims to describe the long-term plan maps of the ERP's research agenda that will be made for SMEs in Indonesia.
\end{abstract}

Keywords: ERP,SME, Indonesia

\section{Pendahuluan}

Berdasarkan Badan Pusat Statistik (BPS) dan Kementerian Koperasi dan UKM pada tahun 2006 jumlah UKM di Indonesia telah mencapai 48.9 juta. UKM di Indonesia telah mampu membuktikan dapat menyediakan 85.4 juta peluang kerja serta dapat berkontribusi 1.778 .75 milliar Rupiah atau bernilai $53.3 \%$ dari PDB (Produk Domestik Bruto) nasional [1]. Persentase tersebut sampai saat ini berjalan konstan sejak tahun 2004 dikarenakan krisis ekonomi global yang terjadi [2]. Namun, persentase tersebut diharapkan akan terus meningkat pada tahuntahun mendatang dikarenakan pertumbuhan ekonomi Indonesia yang semakin membaik. Data global telah menunjukkan kontribusi yang signifikan dari UKM di mana rata-rata $95 \%$ dari kondisi ekonomi di sebagian besar negara bergantung pada UKM [3].

Semakin ketatnya kompetisi antara UKM dan perusahaan besar, UKM harus mencari keunggulan kompetitif yang dapat membantu mereka dalam meminimalkan biaya dan memaksimalkan keuntungan. Salah satu isu utama yang dihadapi oleh UKM adalah terbatasnya sumber daya dan kemampuan finansial yang dimiliki. Selain itu, sebagian besar dari proses bisnis yang dimiliki oleh UKM masih dilakukan secara manual dan hanya sebagian kecil dari 
UKM yang mampu dalam mengimplementasikan aplikasi untuk membantu kegiatan operasional mereka serta sebagian besar kegiatan operasional yang dilakukan masih terpisah-pisah. Situasi ini mungkin tidak akan berdampak besar karena jumlah transaksi yang dilakukan oleh UKM masih sedikit dan volume dari data yang dimiliki masih mungkin untuk dikelola. Namun, tantangan global saat ini tidak memungkinkan UKM untuk memiliki kondisi tersebut dikarenakan persaingan yang semakin ketat dan UKM seharusnya mulai menyiapkan diri dengan aplikasi yang cukup untuk mendukung pertumbuhan bisnis dan menghadapi kompetisi global.

Aplikasi ERP dapat menjadi salah satu solusi untuk membantu UKM dalam menyederhanakan, mengintegrasikan, dan mengotomatisasi proses bisnis mereka. Pada prakteknya, dengan memanfaatkan aplikasi ERP UKM dapat mengurangi biaya operasional dan meningkatkan performa bisnis mereka seperti peningkatan layanan konsumen, mengurangi lead time, dan lain sebagainya. Dengan kata lain, aplikasi ERP dapat memudahkan dan memfasilitasi interaksi yang kuat antara bagian produksi, penjualan, keuangan, dan pemasaran di mana setiap orang dapat berada dalam satu halaman yang sama. Selanjutnya, dengan menggunakan aplikasi ERP, UKM terbantu dalam perkembangan akan pemahaman atas bagaimana proses bisnis yang berbeda-beda dapat diintegrasikan dan berdampak satu sama lain pada proses-proses tersebut. Pada UKM di Indonesia, kesadaran akan konsep ERP masih sangat kurang, yaitu hanya dibawah $20 \%$, yang berimplikasi pada masih besarnya peluang pasar di Indonesia untuk aplikasi ERP [4]. Berdasarkan studi dari Cindy Jutras pada tahun 2010, sebagian besar UKM di dunia tidak mengimplementasikan aplikasi ERP dikarenakan lima hal [5]. Kelima hal tersebut adalah keterbatasan dana, UKM sudah merasa dapat berfungsi dengan efektif tanpa dibantu dengan aplikasi, kurangnya dukungan (internal) untuk implementasi aplikasi, biaya aplikasi dan layanan konsultasi yang dibutuhkan, dan aplikasi ERP terlalu kompleks untuk digunakan.

Sampai saat ini, aplikasi ERP untuk UKM telah banyak dikembangkan oleh vendor baik untuk aplikasi open source atau proprietary. Aplikasi tersebut secara khusus dibuat untuk UKM dengan harga yang terjangkau dan kemudahan dalam penggunaannya. Kondisi tersebut telah memudahkan dan memperkecil hambatan untuk mengadopsi ERP di UKM. Namun, terkait dengan implementasi aplikasi ERP, UKM juga perlu mempertimbangkan dan merencanakan infrastruktur pendukung untuk aplikasi ERP tersebut (misal server, jaringan, dan lain-lain).

Paper ini mendiskusikan studi implementasi ERP untuk UKM di Indonesia. Bab berikutnya akan menjelaskan riset terkait dan latar belakang teori ERP. Peta rencana jangka panjang riset ERP di UKM akan dijelaskan pada bab 4 dan bab terakhir akan menjelaskan mengenai hasil riset yang telah dilakukan serta riset-riset selanjutnya yang akan dilakukan.

Pada tahun 2010, Cindy Jutras dengan kolaborasi dengan Abeerden Group menyediakan pandangan mendalam dan komprehensif terkait keuntungan dan strategi yang dibutuhkan oleh UKM serta kegiatan yang dibutuhkan dalam kesuksesan implementasi ERP [5]. Yuanqiang Xia, Peter Lok, dan Song Yang pada tahun 2009 mendiskusikan karakteristik pemasaran aplikasi ERP dan UKM di Cina serta faktor-faktor kesuksesan utama dari implementasi ERP [6].

Masing-masing negara memiliki budaya yang berbeda-beda sehingga terdapat beberapa studi yang telah dilakukan untuk mengidentifikasi faktor-faktor kesuksesan kritikal atas implementasi aplikasi ERP. Berdasarkan studi dari Handayani, Kencana, Nusa, dan Yuwono pada tahun 2009 dalam menganalisis implementasi ERP di Badan Usaha Milik Negara (BUMN) dengan studi kasus PT. Timah (Persero) dan PT PLN (Persero), terdapat beberapa faktor kesuksesan utama dalam mengimplementasikan ERP seperti adanya komitmen yang kuat dari manajemen, meminimalkan penyesuaian aplikasi ERP, perencanaan proyek ERP yang baik (misal pemilihan metodologi dan perencanaan migrasi data yang tepat), manajemen perubahan (misal transformasi budaya kerja), serta strategi komunikasi [7]. Berdasarkan Ampairatana Nattawee dan Rotchanakitumnuai Siriluck pada tahun 2008, dukungan manajemen, koordinasi, dan komunikasi yang baik antar tim proyek, serta manajemen perubahan merupakan faktor utama untuk implementasi ERP di UKM Thailand [8]. Pada tahun 2009, Siti Shafrah Shahawai dan Rosnah Idrus telah mendefinisikan metodologi riset untuk mengkaji perspektif atas ERP pada UKM di Malaysia [9].

\section{Latar Belakang}

Enterprise Resource Planning (ERP). Bisnis melibatkan proses yang kompleks dan terdapat berbagai macam aktor yang terlibat. Proses bisnis merupakan sekumpulan kegiatan yang mengambil satu atau beberapa masukan dan menghasilkan keluaran yang dapat memberikan nilai ke konsumen [10]. Dalam rangka penyederhanaan, pengintegrasian dan pengotomatisan proses bisnis, 
suatu perusahaan membutuhkan sistem ERP yang merupakan packaged business software system untuk otomatisasi dan integrasi sebagian besar proses bisnis, penyebaran data dalam satu basis data, serta memproduksi dan mengakses informasi pada lingkungan yang real-time. Sebagai tambahan, aplikasi ERP memperkenalkan "best practices" yang mendefinisikan cara sederhana dalam mengeksekusi suatu proses [10]. Terdapat beberapa keuntungan bisnis atas implementasi ERP, seperti mempercepat respon informasi, meningkatkan interaksi untuk seluruh organisasi, meningkatkan alur pengelolaan pesanan, mengurangi pengelolaan hubungan dengan konsumen, meningkatkan pengiriman produk atau jasa secara tepat waktu, meningkatkan interaksi dengan pemasok sehingga dapat mengurangi biaya operasional, dan mengurangi tingkat inventori [11].

Selain keuntungan yang didapatkan dari aplikasi ERP, terdapat beberapa motivasi lainnya dalam mengimplementasi ERP seperti mengganti sistem yang ada saat ini, menyederhanakan dan menstandarkan sistem, kemudahan dalam mengupgrade sistem, memudahkan hubungan untuk kegiatan global, restrukturisasi perusahaan, dan adanya tekanan persaingan dari kompetitor [11].

Dalam implementasi aplikasi ERP, suatu perusahaan seharusnya membutuhkan manajemen perubahan dan restrukturisasi proses bisnis mereka sehingga dapat lebih efisien. Ketika suatu perusahan memilih untuk implementasi aplikasi ERP, mereka seharusnya menyiapkan beberapa komponen biaya seperti perangkat lunak, perangkat keras, konsultasi, pelatihan, dan tim implementasi. Selain itu, dikarenakan investasi untuk implementasi ERP sangat tinggi maka perusahaan perlu mempertimbangkan tiga komponen utama dalam implementasi ERP yaitu Sumber Daya Manusia (pengetahuan, keahlian, dan perilaku SDM), proses (misal standar prosedur operasional) dan teknologi (perangkat keras dan lunak). Dalam mengimplementasikan aplikasi ERP, perusahaan memiliki beberapa pilihan. Pertama, implementasi vanilla ERP dengan mengadopsi best practices dari vendor. Kerugian dari teknik ini adalah kompetitor memiliki akses yang sama ke aplikasi dan memungkinkan terjadinya gangguan terhadap bisnis untuk 3-5 tahun ke depan. Kedua, implementasi ERP secara parsial (misal hanya untuk beberapa modul) yang dapat berdampak pada terjadinya perubahan pada sebagian proses bisnis di perusahaan tersebut. Ketiga, pengembangan yang dilakukan sendiri dengan melakukan penyesuaian pada aplikasi ERP yang unik dari kompetitor lainnya. Kerugian dari teknik ini adalah analisis dan proses perancangan yang membutuhkan waktu yang lama serta biaya yang sangat mahal [11].

Jika suatu perusahaan memilih untuk melakukan implementasi ERP dengan menggunakan teknik vanilla atau parsial, maka perusahaan tersebut dapat membeli aplikasi paket ERP dari suatu vendor tertentu (misal SAP, Oracle PeopleSoft, dsb) atau menggunakan aplikasi open source ERP (contoh OpenBravo, OpenERP, dan lain-lain).

UKM di Indonesia dan Adopsi Teknologi Informasi (TI) di UKM. Dalam rangka meningkatkan keunggulan kompetitifnya, UKM membutuhkan teknologi informasi dalam mendukung kegiatan operasional mereka. Studi dari Fathul Wahid dan Lizda Iswari [12] pada 146 UKM di Yogyakarta menunjukkan bahwa hanya sebagian kecil dari UKM yang telah mengadopsi TI. Hambatan utama yang mereka alami dalam mengadopsi TI adalah terbatasnya dana yang dimiliki dan kebutuhan untuk TI dalam mendukung kegiatan operasional mereka. Temuan yang sama juga ditunjukkan oleh Budi Triono dan Yan Rianto [13]. Survei yang dilakukan pada 151 UKM menunjukkan bahwa hanya $71 \%$ UKM yang telah menggunakan komputer dalam menunjang kegiatan operasional mereka, di mana sebagian besar penggunaannya hanya untuk proses pencatatan saja.

Adopsi e-commerce pada UKM di Indonesia juga masih rendah seperti yang diperlihatkan oleh Vidi Arini Yulimar [14], Asia Foundation [15], dan Yadi [16]. Studi tersebut menggambarkan bahwa dengan menggunakan e-commerce akan dapat meningkatkan level penjualan dan performa bisnis UKM. Kompatibilitas, dukungan yang tinggi dari manajemen, kesiapan perusahaan, tekanan dari pihak luar, serta keuntungan yang didapatkan adalah faktor-faktor signifikan yang harus ada dalam mengadopsi e-commerce.

Beberapa usaha telah dilakukan dalam meningkatkan adopsi TI di UKM seperti PT Zahir Internasional yang telah mengembangkan aplikasi akuntansi untuk UKM. Mereka menawarkan skema harga dan spesifikasi yang bervariasi untuk disesuaikan dengan kemampuan finansial dari UKM. Pada tahun 2008, PT Zahir telah mengeluarkan paket layanan prepaid yang disebut dengan Zahir Merdeka di mana UKM dapat menyewa aplikasi mereka, sehingga UKM dapat memperkecil pengeluaran mereka. Vendor internasional seperti SAP juga sudah menyediakan versi aplikasi ERP yang ekonomis untuk UKM seperti SAP Business One. Skema pembayaran dan harga yang sangat bervariasi ini diharapkan dapat meningkatkan kesempatan UKM dalam mengadopsi TI untuk meningkatkan performa dan ekspansi bisnis mereka. 
UKM dan Kebutuhannya untuk Aplikasi ERP. Berdasarkan Undang-Undang No 9 tahun 1995, Usaha Kecil didefinisikan sebagai usaha orang perseorangan yang memiliki kekayaaan bersih paling banyak 200 juta Rupiah, tidak termasuk tanah dan bangunan tempat usaha atau memiliki hasil penjualan tahunan paling banyak satu milyar rupiah. Berdasarkan Badan Pusat Statistik (BPS), usaha kecil sangat identik dengan industri rumahan. BPS mengklasifikasi jenis industri berdasarkan jumlah pegawai yang dimiliki: (1) Industri rumahan: 1-4 pegawai, pendapatan $\leq 1$ miliar Rupiah/tahun; (2) Industri kecil: 5-19 pegawai, pendapatan $\leq 1$ miliar Rupiah/tahun; (3) Industri menengah: 20-99 pegawai, pendapatan 1-100 miliar Rupiah/tahun; (4) Industri besar: > 100 pegawai, pendapatan $\geq$ 100 miliar Rupiah/tahun.

\section{Analisis dan Pembahasan}

Dengan mempertimbangkan kebutuhan dari UKM dan kurangnya riset ERP untuk UKM yang telah dilakukan, maka laboratorium e-government dan ERP Fakultas Ilmu Komputer Universitas Indonesia telah mendefinisikan peta rencana jangka panjang untuk riset ERP (gambar 2). Dalam riset ini telah didefinisikan tiga ERP sub topik yaitu pengembangan aplikasi simulasi ERP, studi untuk kondisi riset ERP yang telah dilakukan di Indonesia termasuk best practices proses bisnis yang telah dikembangkan, dan analisis terkait infrastruktur yang dibutuhkan dalam melakukan implementasi ERP untuk UKM. Hasil dari riset ini adalah layanan konsultasi dan aplikasi ERP open source yang telah disesuaikan dengan kebutuhan UKM.

Sebelum dilakukan riset ERP ini, langkah awal yang harus dilakukan adalah mengevaluasi riset-riset yang telah dilakukan sebelumnya oleh akademisi, industri, dan pemerintah (misal Kementerian Riset dan Teknologi, Kementerian Koperasi dan UKM, Kementerian Komunikasi dan Informatika, Kementerian Industri, dan institusi pemerintahan lainnya yang terkait). Fokus utama jangka pendek pada riset ini adalah pada industri retail yang merupakan industri kedua terbesar di Indonesia (gambar 1).

Masing-masing UKM memiliki proses bisnis dan lesson learned yang berbeda-beda sehingga kegiatan riset selanjutnya yang harus dilakukan adalah melakukan analisis perbandingan antara UKM dan best practices umum yang telah diakui dan digunakan oleh banyak perusahaan global sehingga dapat didefinisikan generalisasi proses bisnis yang sesuai dengan UKM di industri retail Indonesia. Pada tahapan ini dilakukan juga identifikasi terkait isu-isu adopsi ERP di UKM dan karakteristik utama dari UKM di Indonesia. Selanjutnya, dilakukan analisis dan pendefinisian model kemapanan dengan berkolaborasi dengan sekolah TI di Copenhagen, Denmark.

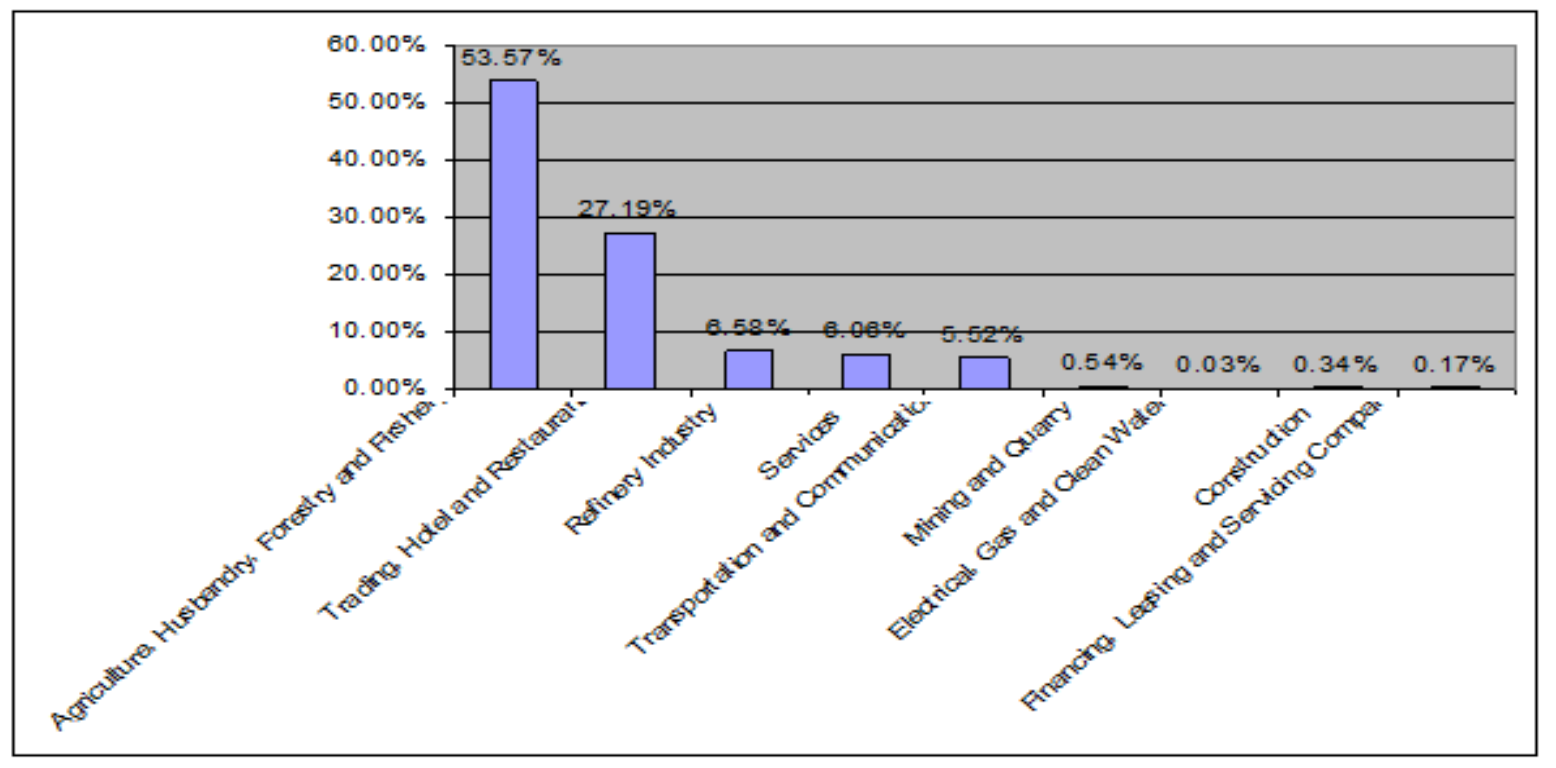

Gambar 1. Distribusi UKM di Indonesia pada tahun 2006 berdasarkan tipe industri. 


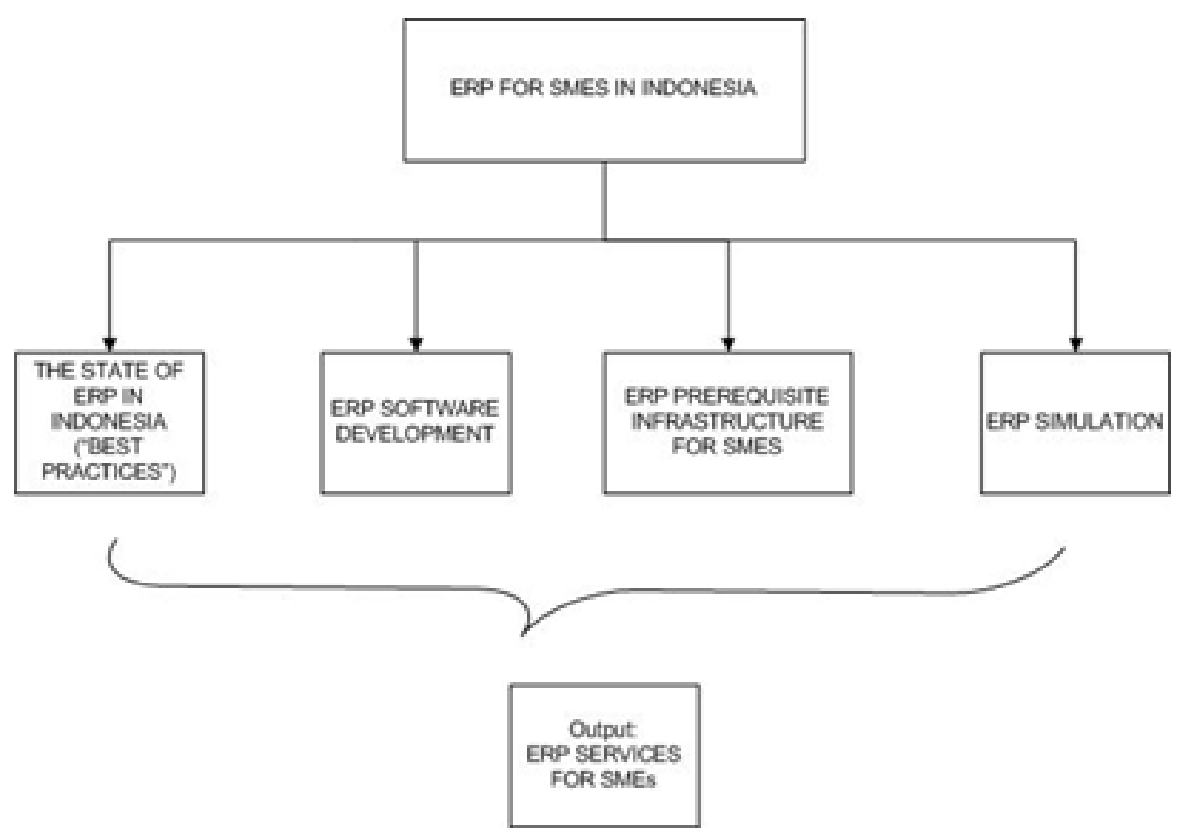

Gambar 2. Klasifikasi dari riset ERP.

Berdasarkan hasil kegiatan riset di atas kemudian akan dikembangkan prototipe aplikasi ERP untuk UKM dengan melakukan penyesuaian pada aplikasi open source ERP yang ada saat ini seperti OpenBravo, OpenERP, dsb. Aplikasi open source ERP tersebut akan dianalisis fungsionalitas/modul yang dimiliki serta arsitektur dari aplikasi tersebut. Selanjutnya, akan dilakukan studi terkait infrastruktur yang dibutuhkan untuk implementasi ERP seperti arsitektur (two/threetier architecture, service oriented architecture, etc), perangkat keras (contohnya server), dan jaringan.

Topik penting lainnya yang akan dianalisis dalam riset ini adalah identifikasi waktu dan pada kondisi apa UKM seharusnya mengimplementasikan aplikasi ERP dengan mempertimbangkan investasi yang mahal. Selain itu, aplikasi simulasi ERP dapat digunakan untuk mendapatkan pemahaman konsep ERP yang terintegrasi bagi manajemen dan personil perusahaan. Studi dari Pierre-Majorique Leger pada tahun 2006 menujukkan bahwa permainan simulasi ERP telah terbukti menjadi strategi pedagogi yang cukup efektif untuk mengajarkan konsep ERP [17].

\section{Kesimpulan}

UKM telah terbukti dapat memberikan kontribusi yang signifikan terhadap pertumbuhan ekonomi di Indonesia. Dalam rangka meningkatkan keunggulan kompetitif, UKM membutuhkan sumber daya yang efektif dan efisien. Aplikasi ERP dapat menjadi salah satu solusi dalam meningkatkan performa UKM.

Peta sistematis terkait riset ERP diperlukan untuk menyediakan layanan konsultasi dan aplikasi ERP open source ke UKM. Beberapa topik riset dapat dilakukan untuk mencapai tujuan riset tersebut di antaranya yaitu analisis kondisi terkini riset ERP yang telah dilakukan di Indonesia, pengembangan aplikasi open source dan aplikasi simulasi ERP yang dapat digunakan untuk memperkenalkan konsep ERP, serta infrastruktur yang diperlukan oleh UKM untuk melakukan implementasi ERP.

\section{Referensi}

[1] S. Sukandar, Kontribusi UKM terhadap PDB Capai 53.3\%, Media Indonesia Online, www.mediaindonesia.com, 2007, retrieved August 2, 2010.

[2] Majalah Pusat Informasi Perkoperasian, Dewan Koperasi Indonesia, XXIV/2007, http://www.majalahpip.com/majalah/treeBuilder.php?pID=11\&tI $\mathrm{D}=856 \#$, 2007, retrieved June 20, 2010

[3] V. Kotelnikov, "Small and Medium Enterprises and ICT" In Asia-Pacific Development Information ProgrammeUNDP, p. 27, 2007.

[4] Koran Tempo, 80 Persen UKM Belum Implementasikan ERP, http://arsip.net/id/link.php?lh=XQZVWwcE A1VT, 2002, retrieved August 1, 2010. 
[5] Aberdeen Research, ERP in SME: Fueling Growth and Profits,

http://www.aberdeen.com/aberdeenlibrary/6526/RA-enterprise-resourceplanning.aspx, 2010, retrieved at June 25, 2010.

[6] Y. Xia, P. Lok, \& S. Yang, "The ERP Implementation of SME in China" In 6th International Conference on Service Systems and Service Management, pp. 135-140, 2009.

[7] K.P. Handayani, R. Nusa, \& Y. Budi, "Implementasi Aplikasi Enterprise Dalam Mendukung Tata Kelola TI BUMN Di Indonesia Studi Kasus: Pt Timah, Tbk dan PLN," Jurnal Sistem Informasi Fasilkom UI, 2009.

[8] N. Ampairatana \& S. Rotchanakitumnuai, "Developing ERP implementation success factors of Thai SMEs" In Proceedings of the Greater Mekong Subregion Academic and Research Network (GMSARN) International Conference, 2008.

[9] S.S. Shahawai \& R. Idrus, "Research Methodology for Assessing Malaysian SMEs perspective on ERP” In Third Asia International Conference on Modelling \& Simulation, pp. 407-421, 2009.

[10] E.F. Monk \& B.J. Wagner, Concepts in Enterprise Resource Planning, 3rd edition, Thomson, 2008.

[11] M. Sumner, Enterprise Resource Planning, Prentice Hall, Edwardsville, 2005.
[12] F. Wahid \& L. Iswari, "Adopsi TI oleh Usaha Kecil Menengah di Indonesia", Seminar Nasional Aplikasi Teknologi Informasi (SNATI), 2007.

[13] B. Triyono, Y. Rianto, et al., Strategi Peningkatan Kemampuan Adopsi Teknologi Informasi untuk Meningkatkan Daya Saing UKM, 2007.

[14] V.A. Yulimar, "Analisis Faktor-Faktor yang Mempengaruhi Pengadopsian E-Commerce dan Pengaruhnya Terhadap Kinerja Perusahaan (Studi pada Perusahaan Kecil dan Menengah di Indonesia)," Master Thesis, Magister of Managemen, UNDIP, Indonesia, 2006.

[15] The Asia Foundation-Castle Asia, SMEs and E-Commerce in Indonesia, http://www.asiafoundation.org/pdf/SMEsurv ey_Indo.pdf, 2002, retrieved August 10, 2010.

[16] Y.S.A. Suriadinata, Penelitian Pemanfaatan Teknologi Informasi dan Komunikasi oleh UKM Eksportir di Indonesia, http://www.pegasus.or,id, 2001, retrieved August 11, 2010.

[17] P.-M. Leger, Using a Simulation Game Approach to Teach ERP Concepts, HEC Montreal, 2006. 